\title{
PARAMETER POPULASI IKAN BAWAL PUTIH (Pampus argenteus) DI PERAIRAN TARAKAN, KALIMANTAN TIMUR
}

\section{POPULATION PARAMETERS OF WHITE POMFRET (Pampus argenteus) IN TARAKAN WATERS, EAST KALIMANTAN}

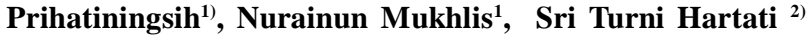 \\ ${ }^{1)}$ Balai Penelitian Perikanan Laut, Muara Baru-Jakarta \\ 2) Pusat Penelitian dan Pengembangan Perikanan \\ Teregistrasi I tanggal: 07 Juli 2014; Diterima setelah perbaikan tanggal: 23 November 2015; \\ Disetujui terbit tanggal: 26 November 2015 \\ e-mail: Prie_nining@yahoo.com
}

\begin{abstract}
ABSTRAK
Ikan bawal putih (Pampus argenteus) mempunyai nilai ekonomis penting dan sebagai salah satu komoditas unggulan di perairan Tarakan. Informasi tentang biologi perikanan ikan tersebut masih terbatas. Penelitian ini bertujuan untuk mengestimasi parameter populasi meliputi pertumbuhan, umur, mortalitas dan tingkat eksploitasi ikan bawal putih. Data frekuensi panjang bulanan dikumpulan pada Februari - Nopember 2013 dengan bantuan enumerator. Sebaran frekuensi panjang ikan dipisahkan kedalam sebaran normal menggunakan metode Bhattacharya pada progran FiSAT (FAO-ICLARM Stock Assessment Tools). Estimasi parameter populasi dengan aplikasi model analitik menggunakan program ELEFAN-1(Electronic Length Frequency Analysis). Hasil penelitian menunjukkan ukuran panjang ikan bawal putih berkisar antara $9,0 \mathrm{~cm}-35,0 \mathrm{cmFL}$. Hubungan panjangberat ikan bawal putih yang tertangkap dengan jaring insang bersifat allometrik negatif mengikuti persamaan $\mathrm{W}$ $=0,187 \mathrm{~L}^{2,374}$. Nilai rata-rata panjang ikan pada saat pertama kali tertangkap $(\mathrm{Lc})$ sama dengan ukuran pertama kali matang gonad (Lm). Laju pertumbuhan (K) sebesar 0,52/tahun dan panjang asimptotik (LO) sebesar 37,28 cmFL. Persamaan pertumbuhan dari Von Bertalanffy sebagai $\mathrm{L}_{\mathrm{t}}=37,28\left(1-\mathrm{e}^{-0,52(\mathrm{t}+0,07)}\right)$. Mortalitas alami (M) adalah 1,11/tahun, mortalitas karena penangkapan $(\mathrm{F})=1,65 /$ tahun dan mortalitas total $(\mathrm{Z})=1,65 /$ tahun. Laju pengusahaan (E) sebesar 0,60 berarti tingkat eksploitasinya sudah melebihi dari nilai optimal $(E=0,5)$ atau populasi ikan bawal putih dalam keadaan lebih tangkap (over exploited). Untuk itu diperlukan kebijakan pengelolaan secara hati-hati dengan mempertimbangkan aspek biologi dan aspek penangkapan yang sedang berjalan.
\end{abstract}

\section{KATA KUNCI: Pampus argenteus, parameter populasi, Tarakan}

\begin{abstract}
White pomfret (Pampus argenteus) is one of the economically important fish and includes leading commodity in Tarakan waters. Information of fishing biology of those species were still limited. This study aims to determine the population parameters including growth, age, mortality and exploitation rate of white pomfret. Monthly length frequency data have been collected by enumerator from February to November 2013. Fish lengthfrequency distribution was separated into a normal distribution using the Bhattacharya method with software of FiSAT (FAO-ICLARM Stock Assessment Tools). Estimation of population parameters were use analytical model application with ELEFAN-1(Electronic Length Frequency Analysis) program. The results showed that lengths distribution of white pomfret ranged beetwen $9.0 \mathrm{~cm}-35.0 \mathrm{cmFL}$. Length-weight relationship was negatively allometric. Estimating the average length at first captured $(L c)$ was equal with average length at first maturity $(L m)$ with growth equation of $L t=37.28\left(1-e^{-0,52(t+0.07)}\right)$. Natural mortality $(M)$ was $1.11 /$ year, fishing mortality $(F)$ was $1.65 /$ yearand total mortality $(Z)$ was $1.65 /$ year. The exploitation rate $(E)$ was 0.60 . It is mean that more higher than optimal exploitation so that the white pomfret fish population in a state of over fished. It is necessary to better policy in the management of white pomfret through precaution approach and describing of biologycal and fishing aspect in Tarakan, Kalimantan Timur.
\end{abstract}

KEYWORDS: Pampus argenteus, population parameter,Tarakan

\section{PENDAHULUAN}

Ikan demersal khususnya bawal putih (Pampus argenteus) merupakan komoditas perikanan unggulan di perairan Tarakan, Kalimantan. Permintaan pasar terhadap ikan bawal putih terus meningkat disertai dengan harga Korespondensi penulis:

Balai Penelitian Perikanan Laut-Muara Baru, Jakarta

Jl. Muara Baru Ujung, Komp. PPS Nizam Zachman-Jakarta Utara yang relatif tinggi dibanding jenis ikan lainnya. Pada ukuran berat antara 0,3-0,4 kg umumnya dipasarkan secara lokal dengan harga antara 35.000-90.000 rupiah/kg. Ukuran ikan yang lebih besar sekitar 0.7-1,2 kg/ekor dengan harga antara 130.000-220.000 rupiah/kg umumnya diekspor dalambentuk beku ke China, Korea, Jepang, Malaysia, Singapore dan Thailand. 
Bawal putih tergolong kelompok ikan yang mampu berkembang di wilayah estuaria dan sedikit berlumpur. Penyebaran ikan bawal putih adalah ke seluruh Indo-Pasifik Barat dari Teluk Persia ke Indonesia, Jepang, Barat dan Barat Daya Korea dan Cina bagian Timur (Haedrich, 1984). Daerah penangkapan ikan bawal putih di Indonesia yang terbesar adalah di perairan Kalimantan.

Ikan bawal putih dalam bahasa perdagangan dikenal dengan nama Silver pomfret termasuk kelompok famili Stromateidae, dengan ciri-ciri antara lain bentuk badan pipih dan tinggi sehingga hampir menyerupai belah ketupat, berwarna putih keperakan di sisi bagian bawah dan keabu-abu di bagian sisi atas, Permukaan tubuh ditutupi dengan bintik-bintik hitam kecil. Panjang badannya bisa mencapai $60 \mathrm{~cm}$. Menurut FAO (1999), tingkah laku ikan bawal putih hidup bergerombol di dasar perairan atau kolom air perairan dekat pantai sampai kedalaman $100 \mathrm{~m}$.

Ttren produksi ikan bawal putih di Kalimantan Timur meningkat dari tahun 2001 sebesar 1.553 ton menjadi 2.430 ton pada tahun 2005 dan tahun 2010 sebesar 1.957 ton (Anonimus, 2011). Semakin meningkatnya produksi ikan bawal putih tersebut, maka diperlukan upaya pengelolaan agar tingkat penangkapan tidak mengganggu kelestarian sumberdayanya. Informasi tentang parameter popuasi ikan bawal putih telah dilakukan dari negara Korea (Lee \& Kim,1992), Kuwait (Morgan, 1985), Cina (Liming \& Yongsong, 2005) dan Teluk Benggala (Mustafa, 1999). Penelitian ini bertujuan untuk mengestimasi beberapa parameter populasi meliputi pertumbuhan, umur, mortalitas dan tingkat eksploitasi ikan bawal putih di perairan Tarakan, Kalimantan Timur.

\section{BAHANDANMETODE Pengumpulan Data}

Pengukuran panjang dan berat ikan bawal putih dilakukan oleh enumerator pada bulan Februari November 2013. Sampel ikan diperoleh dari pengumpul ikan di Tarakan, merupakan hasil tangkapan jaring insang, dengan ukuran mata jarring antara 4-6 in. Panjang ikan diukur dengan ketelitian $0,1 \mathrm{~cm}$ dan berat individu dengan ketelitian 1,0 gram. Sampel gonad ikan yang diperoleh setelah dilakukan pembedahan, diamati secara visual untuk mengetahui tingkat kematangan gonad (TKG), mengacu pada Holden \& Raitt (1974), yang terdiri atas lima tingkatan disajikan pada Tabel Lampiran 1.

\section{Analisis Data \\ Hubungan Panjang-Berat}

Hubungan panjang-berat mengacu pada Effendie (1979) dengan formula:
$\mathrm{W}=\mathrm{aL}^{\mathrm{b}}$

dimana :

$\mathrm{W}=$ Berat $($ gram $)$;

$\mathrm{L}=$ panjang $(\mathrm{cm})$

$\mathrm{a}=$ intersep (perpotongan kurva hubungan panjangbobot dengan sumbu Y)

$\mathrm{b}=\operatorname{kemiringan}($ slope $)$

Untuk menguji nilai $\mathrm{b}=3$ atau $\mathrm{b} \neq 3$ dilakukan uji $-\mathrm{t}$ (uji parsial) pada taraf nyata $95 \%$. Hipotesis terhadap nilai $b$ dengan asumsi:

$\mathrm{H}_{0}: \mathrm{b}=3$, hubungan panjang dan bobot adalah isometrik

$\mathrm{H}_{1}: \mathrm{b} \neq 3$, hubungan panjang dengan bobot adalah allometrik

Pola hubungan panjang-bobot bersifat allometrik positif, bila $\mathrm{b}>3$ (pertambahan berat lebih cepat daripada pertambahan panjang), dan allometrik negatif, bila $\mathrm{b}<3$ (pertambahan panjang lebih cepat daripada pertambahan berat).

\section{Panjang pertama kali tertangkap (Lc) dan pertama kali matang gonad ( Lm)}

Pendugaan ukuran pertama kali tertangkap dilakukan dengan membuat grafik hubungan antara panjang ikan (sumbu X) dengan jumlah ikan (sumbu Y) sehingga diperoleh kurva berbentuk sigmoid. Nilai length at first capture (Lc) yaitu panjang pada $50 \%$ pertama kali tertangkap dihitung dengan persamaan sebagai berikut (Jones dalam Sparre \& Venema, 1999):

$$
\begin{aligned}
& S_{L} \text { est }=\frac{1}{1+\exp \left(S_{1}-S_{2} * L\right)} \\
& \operatorname{Ln}\left[\frac{1}{S L}-1\right]=S_{1}-S_{2} * L \ldots \ldots \\
& L_{50 \%}=\frac{S_{1}}{S_{2}}
\end{aligned}
$$

dimana :

SL $\quad=$ kurva logistik; $\mathrm{S}_{1}=\mathrm{a} ; \mathrm{S}_{2}=\mathrm{b}$

$\mathrm{S}_{1}$ dan $\mathrm{S}_{2}=$ konstanta pada rumus kurva logistik

Pendugaan panjang pertama kali matang gonad (length at first maturity) (Lm) dilakukan sesuai dengan prosedur penghitungan yang dilakukan oleh Udupa (1986), melalui rumus :

$\mathrm{m}=\mathrm{Xk}+\mathrm{X} / 2-\left(\mathrm{X} \Sigma \mathrm{P}_{\mathrm{i}}\right.$ 
dimana :

$\mathrm{m}=$ log ukuran ikan saat pertama matang gonad

$\mathrm{Xk}=\log$ ukuran ikan dimana 100\% ikan sampel sudah matang

$\mathrm{X}=$ selang log ukuran (log size increment)

$\mathrm{P}_{\mathrm{i}}=$ proporsi ikan matang pada kelompok ke-i

Rata-rata ukuran ikan pertama matang gonada diperoleh dari nilai $\operatorname{antilog}(\mathrm{m})$.

\section{Parameter Pertumbuhan}

Penentuan kelompok ukuran (kohort) dilakukan menggunakan metode Bhattacharya dari perangkat lunak FiSAT II. Pendugaan nilai koefesien pertumbuhan $\mathrm{L}_{\text {, dan }}$ $\mathrm{K}$ dilakukan dengan menggunakan metode ELEFAN - I (Electronic Length Frequency Analysis) dan Gulland \& Holt plot. Nilai dugaan umur teoritis pada saat panjang ikan sama dengan nol $\left(\mathrm{t}_{0}\right)$ diperoleh melalui persamaan Pauly (1984):

$\log -\left(t_{0}\right)=-0,3922-0,2752 \log \mathrm{L}-1,038 \log \mathrm{K}$.

Ketiga nilai estimasi parameter pertumbuhan tersebut dimasukkan ke model pertumbuhan Von Bertalanffy. Pola pertumbuhan ikan bawal putih diperkirakan dengan menggunakan rumus Von Bertalanffy (Sparre \& Venema, 1998) sebagai berikut:

$L_{t}=L \infty\left(1-e^{-k(t-t o)}\right)$

dimana :

$\mathrm{L}_{\mathrm{t}}=$ ukuran panjang ikan pada saat umur $\mathrm{t} \operatorname{tahun}(\mathrm{cm})$

$\mathrm{L}_{\infty}=$ panjang maksimum ikan yang dapat dicapai

$\mathrm{t}_{0}=$ umur ikan teoritis pada saat panjangnya $0 \mathrm{~cm}$

$\mathrm{K}=$ Koefisien pertumbuhan

\section{Mortalitas}

Mortalitas total (Z) dalam suatu kegiatan perikanan tangkap sangat penting untuk menganalisis dinamika populasi atau stok ikan. Mortalitas dapat dibedakan dalam mortalitas alami (M) dan mortalitas karena penangkapan (F). Mortalitas total dapat diduga dari pergeseran kelimpahan kelompok umur dan dari analisis kurva hasil tangkapan menggunakan data frekuensi panjang (Sparre \& Venema, 1999). Mortalitas total dihitung menggunakan rumus:

$\mathrm{Z}=\mathrm{M}+\mathrm{F}$

Mortalitas alami (M) diestimasi dengan metode persamaan empiris Pauly (1983) dengan rumus :

$\operatorname{Ln} M=-0,152-0,279 * \operatorname{LnL} \infty+0,6543 * \operatorname{LnK}+0,463 * \operatorname{Ln} \mathrm{T} . . .(9)$ dimana:

$\mathrm{M}=$ mortalitas alami per tahun

$\mathrm{L} \infty$ = panjang maksimum ikan yang dapat dicapai

$\mathrm{K}=$ koefisien pertumbuhan

$\mathrm{T}=$ suhu rata-rata tahunan $\left({ }^{\circ} \mathrm{C}\right)$

Mortalitas penangkapan (F) dan laju eksploitasi (E) diperoleh dari persamaan, Pauly (1983) sebagai berikut:

$\mathrm{Z}=\mathrm{F}+\mathrm{M}$

$\mathrm{E}=\mathrm{F} / \mathrm{Z}$

\section{HASIL DANBAHASAN}

\section{Hasil \\ Sebaran Ukuran Panjang}

Total contoh ikan bawal putih yang diperoleh pada bulan Februari - Nopember 2013 sebanyak 1.255 ekor. Sebaran ukuran panjang ikan antara 9,0 cm -35,0 cmFL atau rata-rata $17,93 \mathrm{cmFL}$ dengan modus $18,0 \mathrm{cmFL}$. Gambar 1 menunjukkan bahwa struktur ukuran panjang ikan bawal putih mempunyai pola sebaran normal dan mengalami pergeseran dan pergerakan modus. Pada bulan Februari, terdapat 2 kelompok umur (kohort) yaitu pada ukuran $11,0 \mathrm{cmFL}$ dan 20,0 cmFL dan modus terdapat pada ukuran panjang 11,0 cmFL. Bulan Maret dan April terdapat pergeseran modus yaitu pada ukuran panjang 18,0 cmFL. Bulan Mei, modus bergerak ke kiri (ukuran ikan yang lebih kecil) yaitu pada ukuran panjang 16,0 cmFL. Bulan Juni dan Juli, modus bergerak ke kanan lagi yaitu pada ukuran panjang 17,0 cmFL. Bulan Agustus dan September bergerak ke kanan yaitu pada ukuran panjang 20,0 cmFL. Hal ini menunjukkan adanya pertumbuhan ikan bawal putih. Modus bulan Oktober dan Nopember bergerak ke kiri (ukuran ikan lebih kecil) yaitu pada ukuran 16,0 cmFL.

\section{Hubungan Panjang-Berat}

Persamaan eksponensial hubungan panjang bobot ikan bawal putih bersifat allometrik negatif (pertambahan panjang lebih cepat dibandingkan pertambahan beratnya) dengan nilai b sebesar 2,374 dan nilai koefesien korelasi sebesar 0,916 (Gambar 2) dengan persamaan $\mathrm{W}=$ $0,187 \mathrm{~L}^{2,374}$. Hal ini menunjukkan adanya korelasi positif dan kuat antara panjang dengan berat ikan bawal putih.

\section{Panjang Pertama Kali Tertangkap (Lc) dan Pertama Kali Matang Gonad (Lm)}

Untuk mempertahankan keseimbangan stok ikan dalam suatu populasi sangatlah penting untuk memberikan kesempatan berreproduksi setidaknya sekali dalam seumur hidup, oleh karena itu rata-rata ukuran panjang pertama kali tertangkap (Lc) harus lebih besar dari rata- 
rata ukuran pertama kali matang gonad (Lm). Rata-rata ukuran panjang pertama kali tertangkap (Lc) ikan bawal putih dari hasil penelitian ini adalah 15,90 cm (Gambar 3).

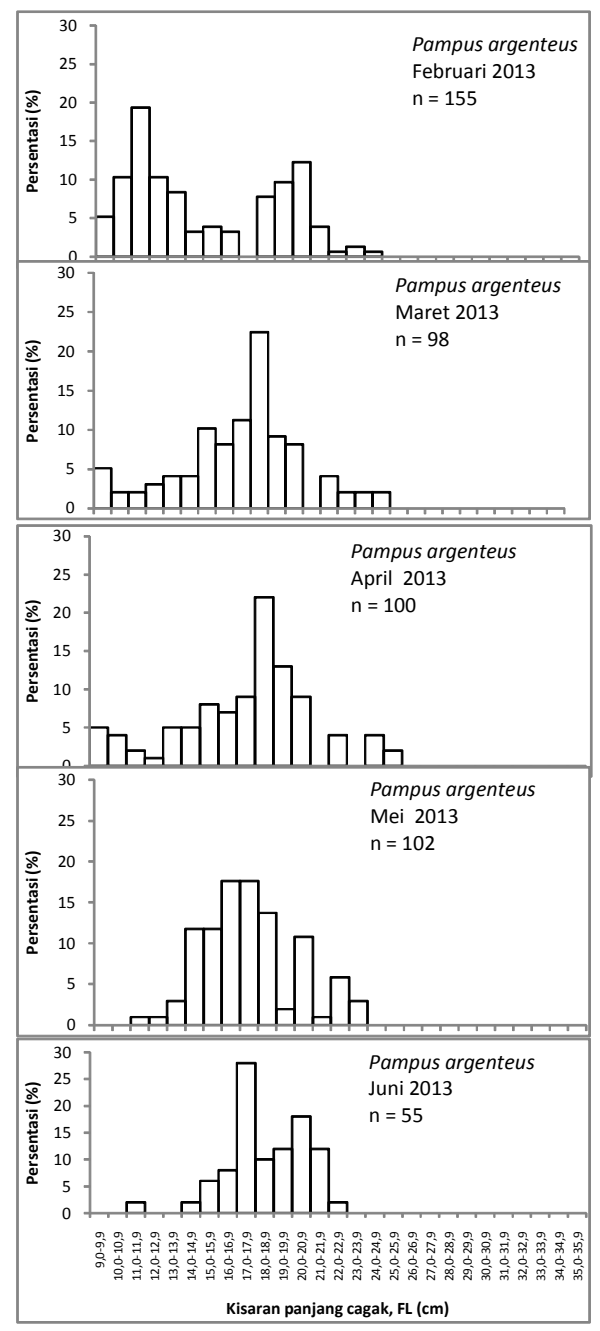

Ukuran pertama kali matang gonad (Lm) adalah $15,98 \mathrm{~cm}$. Perhitungan nilai rata-rata ukuran pertama kali matang gonad (Lm) ikan bawal putih disajikan pada Tabel Lampiran 2

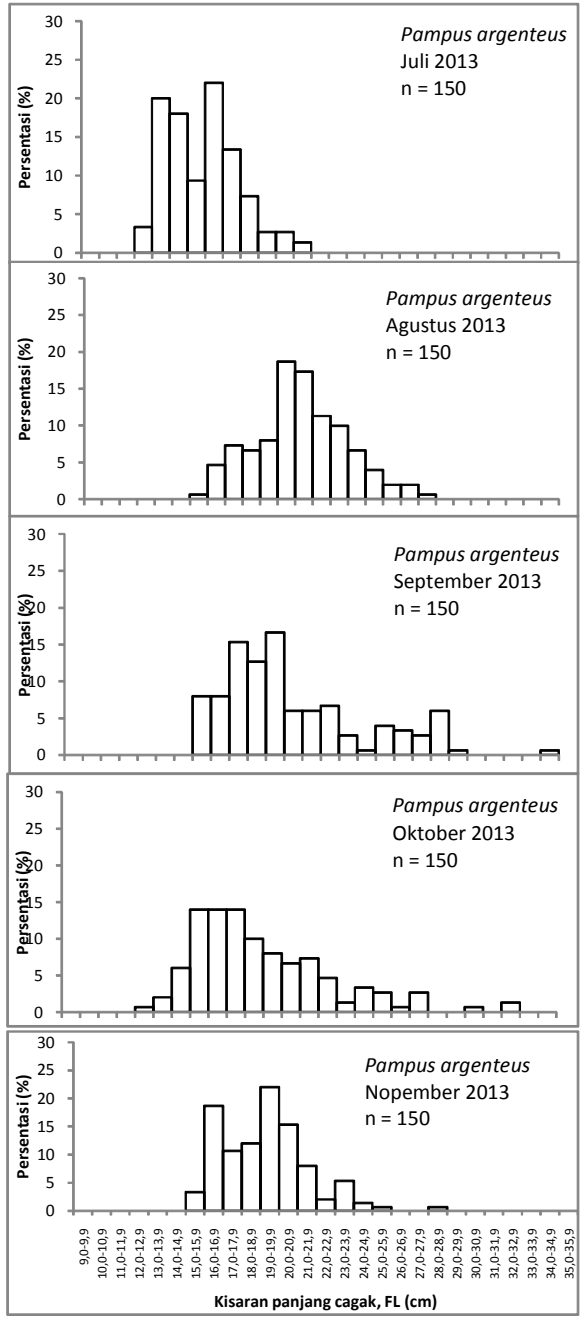

Gambar 1. Sebaran ukuran panjang cagak ikan bawal putih (P. argenteus) yang didaratkan di Tarakan, 2013. Figure 1. Fork length distribution of white pomfret (P. argenteus) landed in Tarakan, 2013.

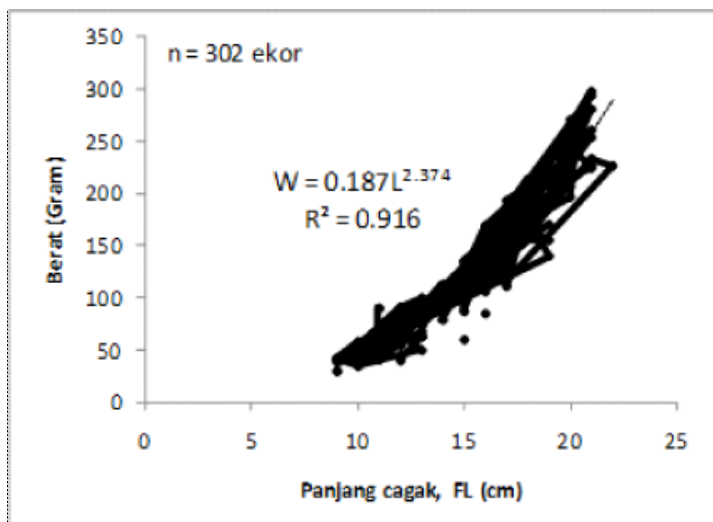

Gambar 2. Hubungan panjang-berat ikan bawal putih $(P$. argenteus) di Tarakan, , 2013.

Figure 2. Length-weight relationship of white pomfret (P. argenteus) in Tarakan, 2013.

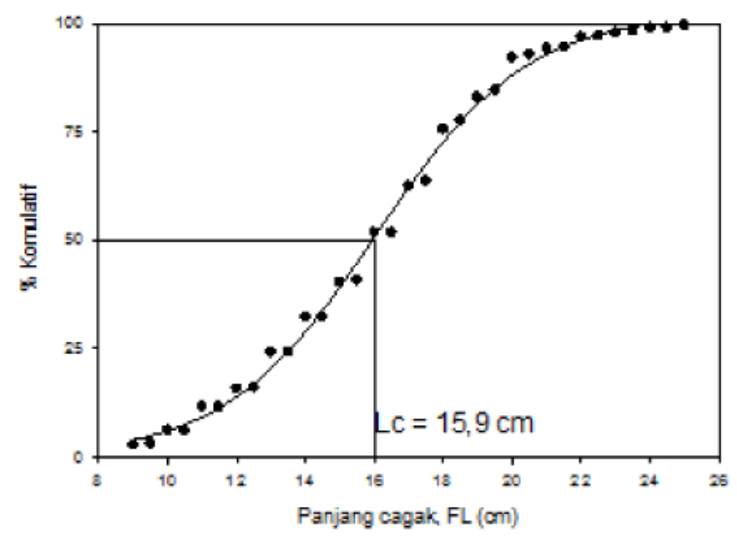

Gambar 3. Grafik menunjukkan ukuran panjang pertama kali tertangkap ikan bawal putih (P. argenteus), di perairan Tarakan.

Figure 3. Curve showing length at first captured $(L c)$ of white pomfret (P. argenteus) caught in Tarakan waters, 2013. 


\section{Parameter Pertumbuhan}

Dari model pertumbuhan Von Bartalanffy, didapat koefesien pertumbuhan ikan bawal putih (K) sebesar 0,52/ tahun. Nilai panjang asimtotik (L., sebesar 37,28 cmFL, dan nilai dugaan umur teoritis pada saat panjang ikan sama dengan nol $\left(\mathrm{t}_{0}\right)$ adalah $0,07 /$ tahun sehingga diperoleh persamaan pertumbuhan ikan bawal putih adalah $\mathrm{Lt}=37,28$ $\left(1-\mathrm{e}^{-0,52(\mathrm{t}+0,07)}\right)($ Gambar 4).

Koefesien pertumbuhan (K) ikan bawal putih sebesar 0,52/tahun dengan panjang total maksimum adalah 35,0

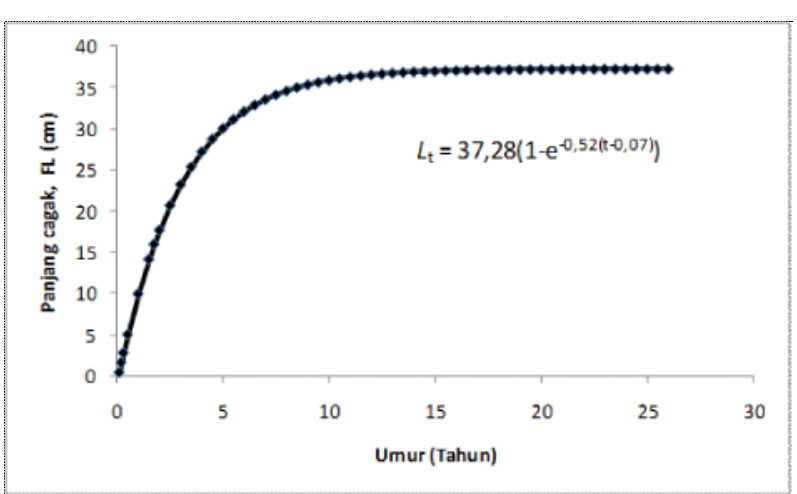

Gambar4. Kurva pertumbuhan von Bertalanffy bawal putih (Pampus argenteus).

Figure 4. Von Bertalanffy growth curve of white pomfret (Pampus argenteus).

\section{Bahasan}

Hubungan panjang berat ikan menggambarkan sifat pertumbuhan ikan. Hubungan panjang berat ikan bawal putih (Pampus argenteus) bersifat allometrik negatif. Menurut Heriyanto (1991) bahwa pertumbuhan ikan bawal putih (Pampus sp.) di perairan utara Jawa Tengah bersifat allometrik negatif dengan persamaan LogW = 3,6974+2,4559 LogL. Faktor-faktor yang menyebabkan hubungan nilai panjang berat adalah faktor dalam (intrinsik) dan luar (ekstrinsik) umumnya susah dikontrol, meliputi sex, umur, parasit dan penyakit. Sedangkan faktor luar yang utama adalah faktor makanan dan suhu perairan. (Effendi, 2002).

Hasil analisis menunjukkan ukuran pertama kali tertangkap sama dengan pertama kali matang gonad (Lc $15,9 \mathrm{~cm}=\mathrm{Lm} \mathrm{15,9)}$. Hal ini perlu kehatia-hatian dalam pengelolaan perikanan ikan bawal putih di Tarakan, Kalimantan Timur karena untuk perikanan berkelanjutan. Nilai Lc harus lebih besar dari Lm atau setidaknya sama. Menurut Amrollahi et al. (2007) nilai Lm ikan bawal putih (P.argenteus) di Teluk Persia bagian Utara sebesar 19,2 cm, Morgan ( 1985) melaporkan bahwa ukuran Lm ikan bawal putih di perairan Kuwait adalah $20,0 \mathrm{~cm}$. Narges et al., (2011) menyatakan bahwa nilai Lc ikan bawal putih di
cmFL atau lebih kecil dari panjang asimtotik (L.,) yang besarnya 37,28 cmFL. Perbedaan antara panjang maksimum yang diperoleh dengan panjang asimtotik, menimbulkan penafsiran bahwa ada ikan berukuran besar lebih dari 35,0 cmFL yang belum tertangkap.

\section{Mortalitas dan Tingkat Eksploitasi (E)}

Mortalitas total (Z) ikan bawal putih adalah 2,76, mortalitas alami $(\mathrm{M})$ adalah 1,11, dan mortalitas karena penangkapan (F) adalah 1,65 dan tingkat eksploitasi (E) diperkirakan yaitu 0,60/tahun (Gambar 5).

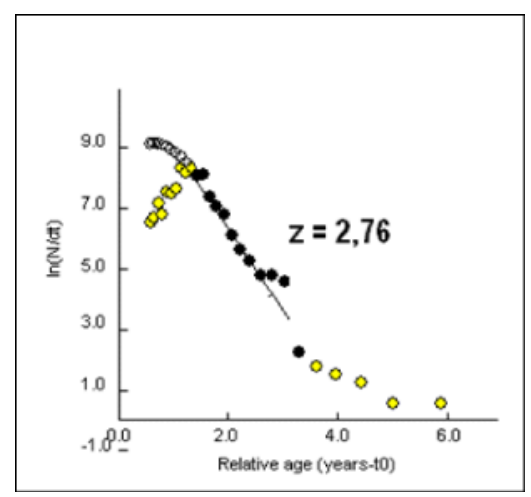

Gambar5. Kurva hasil tangkapan yang dilinierkan berdasarkan data komposisi panjang ikan bawal putih.

Figure 5. The linearized catch curve based on length composition data of white pomfret.

perairan Utara Teluk Persia adalah 10,1 cm FL. Selanjutnya Lin et al.dalam Hashemi et al. (2012) mengemukakan bahwa di Laut Cina Timur diperoleh nilai Lc sebesar 17,0 $\mathrm{cm}$. Oleh karena itu, ikan bawal putih di perairan Kalimantan Timur harus lebih besar dari nilai Lc saat ini ( $>$ Lc $=15,9 \mathrm{cmFL}$ ) untuk memiliki perikanan yang berkelanjutan. Diperlukan upaya pengaturan dengan cara memperbesar ukuran mata jaring insang dari yang sekarang digunakan (4 inci) sehingga diperoleh nilai Lc lebih besar dari Lm.

Nilai L,ikan bawal putih sebesar 37,28 cmFL dan laju pertumbuhan $(\mathrm{K})$ sebesar $0,52 /$ tahun. Hal ini berbeda dengan hasil penelitian Narges (2011) menyatakan bahwa estimasi parameter pertumbuhan von bertalanffy Pampus argenteus di Utara Teluk Persia sebesar $\mathrm{L}_{,}=33,9 \mathrm{cmFL}$ dan $\mathrm{K}=0,55 /$ tahun dan $\mathrm{t}_{0}=-0,16$ tahun. Umur ikan bawal puth dari persamaan $\mathrm{L}_{\mathrm{t}}=37,28\left(1-\mathrm{e}^{-0,52(\mathrm{t}+0,07)}\right)$ pada saat pertama kali tertangkap $\mathrm{Lc}=15,90 \mathrm{~cm}$ dan matang gonad $(\mathrm{Lm}=15,98 \mathrm{~cm})$ diduga berumur 1,75 tahun .

Hasil estimasi parameter pertumbuhan ikan bawal putih di daerah penangkapan yang berbeda diantaranya Laut Jawa (Indonesia), Teluk Persia, Teluk Benggala, Korea telah diteliti (Tabel 1). Dari beberapa parameter populasi yang berbeda, didapatkan panjang maksimum ikan yang dapat 
dicapai setiap wilayah dan laju pertumbuhan yang berbeda pula dan rentang waktu yang luas. Panjang asimtot ikan bawal putih berkisar antara 28,0-42,2 cm FL. Panjang asimtot $\left(\mathrm{L}^{\infty}\right)$ terkecil diperoleh dari sampel di Teluk Benggala dan tertinggi dari Teluk Persia. Nilai laju pertumbuhan (K) berkisar antara 0,26-0,99. Variasi nilai Lodan K di berbagai daerah mungkin karena adanya perbedaan ekologi, kondisi fisiologis ikan, variabilitas makan, tekanan penangkapan dan metode sampling (Biswas, 1993).

Tabel 1. Parameter pertumbuhan ikan bawal putih (P. argenteus) dari beberapa daerah penangkapan.

Table 1. Parameters growth of white pomfret (P. argenteus) of some fishing ground.

\begin{tabular}{ccll}
\hline L $\infty$ (cmFL) & K (per tahun) & \multicolumn{1}{c}{ Lokasi/Location } & \multicolumn{1}{c}{ Sumber/Source } \\
\hline 32,5 & 0,55 & Teluk Persia (Kuwait) & Morgan (1985) \\
32,5 & 0,95 & Laut Jawa (Indonesia) & Dwiponggo et al. (1986) \\
33,6 & 0,26 & Korea & Lee at al. (1992) \\
28,0 & 0,63 & Teluk Benggala & Mustafa (1993) \\
29,8 & 0,53 & Teluk Benggala & Mustafa (1999) \\
41,0 & 0,92 & Teluk Persia (Iran) & Parsamanesh et al (2003) \\
37,5 & 0,99 & Estuarin Musa & Salari (1996) \\
42,4 & 0,53 & Teluk Persia (Irak) & Mohamed (2008) \\
33,9 & 0,55 & Teluk Persia (Iran) & Narges et al (2011) \\
37,28 & 0,52 & Tarakan, Kalimantan Timur & Penelitian ini \\
$28,0-42,4$ & $0,26-0,99$ & Kisaran & \\
\hline
\end{tabular}

Keterangan/Remark : FL $=$ Fork length.

Menurut Aziz et al. (1992), perbedaan parameter pertumbuhan disebabkan perbedaan lama waktu, musim, ukuran ikan, alat tangkap yang digunakan dan daerah penangkapan pada saat sampling. Widodo (1988) juga menyatakan perbedaan nilai parameter pertumbuhan ini lebih dipengaruhi oleh komposisi ikan contoh dengan cara atau metode yang digunakan. Jika ikan-ikan muda lebih banyak tertangkap maka koefisien pertumbuhan akan tinggi dan sebaliknya jika ikan-ikan berumur tua yang banyak tertangkap, maka koefisien pertumbuhan akan rendah. Sparre \& Venema (1999) menyatakan perbedaan nilai $\mathrm{K}$ dapat juga disebabkan oleh kondisi lingkungan perairan.

Tingkat eksploitasi ikan bawal putih dalam penelitian ini termasuk tinggi $(E=0,60)$. Menurut Gulland (1969) bahwa dalam stok yang optimal, kematian ikan karena penangkapan harus sama dengan kematian alami sehingga tingkat eksploitasinya 0,5 tahun $^{-1}$. Hal ini menunjukkan bahwa populasi ikan bawal putih di tarakan, Kalimantan Timur tingkat eksploitasinya lebih tinggi dari optimal sehingga dapat dikatakan bahwa populasi ikan bawal putih dalam keadaan lebih tangkap (overfished) dan diperlukan adanya kebijakan yang lebih baik dalam pengelolaan ikan bawal putih di daerah ini.

\section{KESIMPULAN}

Hubungan panjang-berat ikan bawal putih (Pampus argenteus) di perairan Tarakan bersifat allometrik negatif mengikuti persamaan $\mathrm{W}=0,187 \mathrm{~L}^{2,374}$. Rata-rata panjang ikan pada saat pertama kali tertangkap (Lc) besarnya sama dengan ukuran pertama kali matang gonad (Lm). Analisis parameter populasi diperoleh nilai L, sebesar 37,28 cmFL dan laju pertumbuhan $(\mathrm{K})$ sebesar $0,52 /$ tahun dengan persamaan pertumbuhan $\mathrm{L}_{\mathrm{t}}=37,28\left(1-\mathrm{e}^{-0,52(\mathrm{t}+0,07)}\right)$. Mortalitas karena penangkapan $(\mathrm{F})=1,65 /$ tahun lebih besar dibandingkan mortalitas alami $(\mathrm{M})=1,11 /$ tahun. dan mortalitas total $(Z)=1,65 /$ tahun. Laju pengusahaan $(E)$ adalah 0,60 berarti tingkat eksploitasinya sudah melampaui nilai optimumnya $(E=0,5)$. Pengelolaan perikanan ikan bawal putih dapat dilakukan dengan pengaturan/memperbesar ukuran mata jaring insang lebih dari 4 inci, agar diperoleh nilan Lc lebih besar dari Lm.

\section{PERSANTUNAN}

Tulisan ini merupakan hasil dari kegiatan penelitian dan pemutakhiran data hasil tangkapan, upaya penangkapan dan ukuran kan di WPP 716 (Laut Sulawesi) pada Balai Penelitian Perikanan Laut tahun anggaran 2014.

\section{DAFTAR PUSTAKA}

Anonimus, 2011. Statistik Perikanan Tangkap Indonesia 2010. Direktorat Jenderal Perikanan Tangkap. Kementerian Kelautan dan Perikanan. Jakarta.

Amrollahi, N., Kuchanian, P., Maremmazi, J., Eskandary, Gh \&. and V Yavary, 2007. Spawning season of Pampus 
argenteus (Euphrasen, 1788) in the Northwest of the Persian Gulf and its implications for management. Pakistan Journal of Biological Science. 10(24): 45514554.

Azis, K.A., Muchsin, I. \& M. Boer. 1992. Kajian Dinamika Populasi Ikan-ikan Niaga Utama di Perairan Pantai Barat Bengkulu. Laporan Penelitian. Fakultas Perikanan IPB. Bogor (Tidak dipublikasi)

Biswas, S.P. 1993. Manual of Methods in Fish Biology. South Asia Publishers. Pvt. Ltd, New Delhi: 195 pp.

Dwiponggo, A., Hariati, T., Banon, S., Palomares, M.L. \& D. Pauly. 1986. Growth, Mortality and recruitment of commercially important fishes and penaeid shrimps in Indonesian waters, ICLARM Tech. Rep., 17: 21 pp.

Effendie, M. I. 1979. Metode Biologi Perikanan. Penerbit Yayasan Dewi Sri. Bogor: 112 hal.

2002. Biologi Perikanan. Penerbit Yayasan Pustaka Nusatama. Yogyakarta: 163 hal.

Food Agricultural Organization, 1999. The living marine sources of Western Central Pasific. Spesies identification guide for fishery purpose. Fisheries Department, Rome.

Gulland, J.A. 1969. Manual of Methods for Fish Stock Assessment. Port 1. Fish Population Analysis. FAO Press, FAO Mar. Fish. Sci., 4. Rome: 154 pp.

Haedrich, R.L. 1984. Stromateidae. In: W. Fischer and G. Bianchi (Eds.), FAO species identification sheets for fishery purposes, Western Indian Ocean (Fishing Area 51). FAO, Rome.

Heriyanto, Y. 1991. Pendugaan stok ikan bawal putih (Pampus sp.) di perairan Utara Jawa Tengah. Skripsi. Fakultas Perikanan. Institut Pertanian Bogor. Bogor: 72 hal (Tidak dipublikasi).

Holden, M. J. \& D. F. S. Raitt. 1974. Manual of FisheriesScience. Food and Agriculture Organization. Rome. Part 2. Methods of Resources Investigation and their Application: $135 \mathrm{pp}$.

Lee, D.W. \& Kim, Y.M. 1992. Stock assessment of silver pomfret, in Korean waters, Bull. Natl. Fish. Res. Dev. Agency, Korea. 46: 41-45.
Liming, Sh. \& Q. Yongsong. 2005. Estimation of growth and mortality parameters for Pampus argenteus in Pearl River Estuary and adjacent waters. J. Fish. China, 29(2): 193-197.

Hashemi, SA.R, H.Safikhani \& Vahabnezhad. 2012. Growth, Mortality Parameter and Exploitation Rate of Silver Pomfret ( Pampus argenteus Euphrasen, 1788) in Northwest of Persian Gulf (Khuzestan Coastal Waters, Iran). American-Eurasian J. Agric \& Environ Sci, 12 (8) : $1095-1101)$.

Morgan, G.R. 1985. Stock assessment of silver pomfret Pampus argenteus in Kuwaiti waters. J. Cons. Int. Explor. Mer, 42: 3-10.

Mustafa, G.M. 1993. ELEFAN based growth parameters of white pomfret Pampus argenteus from the Bay of Bengal. Bangladesh J. Zoo., 21(1): 143-149.

Mustafa, M.G. 1999 Population dynamics of penaeid shrimps and demersal finfishes from Traud Fishery in the Bay of Bengal and Implication for the management. PhD thesis, Bangladesh: University of Dhaka (Un published).

Narges, A., K. Preeta, m. Jasem, E. Gholam \& Y. Vahid. 2011. Stock assessment of silver pomfret Pampus argenteus (Euphrasen, 1788) in the Northern Persian Gulf. Turkish Journal of Fisheries and Aquatic Sciences 11:63-68.

Pauly, D. 1983. A selection of simple methods for the assessment of tropical fish stocks. FAO Fish. Circ. 729: $54 \mathrm{pp}$.

Pauly, D. 1984. Some simple methods for the assessment of tropical fish stocks. FAO Fish. Tech. Pap. (234): 52 p.

Sparre, P. \& S. C. Venema. 1998. Introduksi pengkajian stok ikan tropis. Badan Penelitian dan Pengembangan Perikanan. Terjemahan dari Introduction to Tropical fish stock assessment. FAO Fish Tech. Paper. 306.(1) $376 \mathrm{p}$.

Udupa, K. S. 1986. StatisticaL method of estimating the size of first maturity in fish. Fishbyte. ICLARM. Manila. Vol 4 (2); 8-1. 
Prihatiningsih., et al/BAWAL Vol.7 (3) Desember 2015:165-174

Widodo, J. 1988. Population Dynamics and Management of Ikan Layang, Scad Mackerel, Decapterus spp.
(Pisces: Carangidae) in The Java Sea. Ph.D. Dissertation. Univ. Wash. Seattle. 150p (Un published). 
Lampiran 1. Tingkat kematangan gonad ikan

Appendix 1. Gonad maturity stage of fish

\begin{tabular}{|c|c|}
\hline $\begin{array}{c}\begin{array}{c}\text { Tingkat kematangan } \\
\text { gonad/ }\end{array} \\
\text { Gonad maturity stage }\end{array}$ & Keterangan/Remarks \\
\hline I (belum matang) & $\begin{array}{l}\text { Ovarium dan testes, panjang } 1 / 3 \text { rongga perut. Ovarium transparan dan kemerahmerahan. } \\
\text { Telur tidak dapat dilihat dengan mata biasa. }\end{array}$ \\
\hline II (belum matang) & $\begin{array}{l}\text { Panjang ovarium sekitar } 1 / 2 \text { rongga perut. Ovarium transparan dan kemerahmerahan. } \\
\text { Telur belum dapat dilihat dengan mata biasa. }\end{array}$ \\
\hline III (matang) & $\begin{array}{l}\text { Panjang ovarium dan testes sekitar } 2 / 3 \text { rongga perut. Warna ovarium pink-kuning } \\
\text { dan butiran telur sudah tampak. }\end{array}$ \\
\hline IV (matang) & $\begin{array}{l}\text { Panjang ovarium } 2 / 3 \text { memenuhi rongga perut. Ovarium berwarna orange dengan } \\
\text { pembuluh darah sudah mulai kurang jelas. Transparan dan butiran telur terlihat jelas. }\end{array}$ \\
\hline $\begin{array}{c}\mathrm{V} \\
(\text { spent })\end{array}$ & $\begin{array}{l}\text { Ovarium mengerut sampai panjang } 1 / 2 \text { rongga perut sebagai tanda pemijahan tetapi } \\
\text { ada butir-butir telur. }\end{array}$ \\
\hline
\end{tabular}

Sumber/sources : Holden \& Raitt (1974) 
Prihatiningsih., et al/BAWAL Vol.7 (3) Desember 2015:165-174

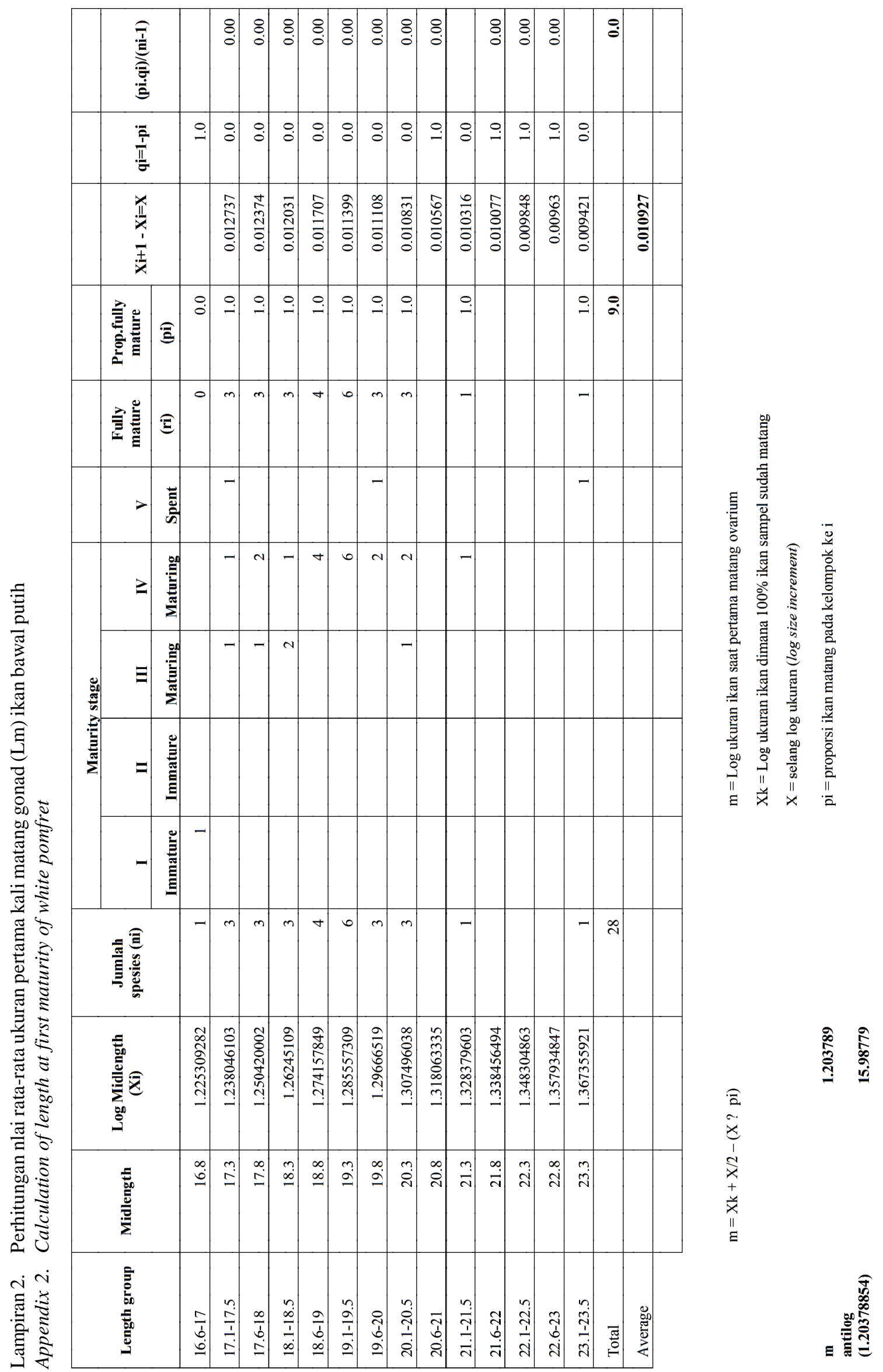

